\title{
SIMULASI KENYAMANAN TERMAL MODEL REKOMENDASI TAMAN AIR BERARSITEKTUR TRADISIONAL BALI PADA TAMAN KOTA I GUSTI NGURAH MADE AGUNG DI DENPASAR
}

\author{
I Wayan Wirya Sastrawan, ST., M.Sc. \\ Dosen Jurusan Teknik Arsitektur, Fakultas Teknik, Universitas Warmadewa, Denpasar-Bali \\ E-mail: wayanwiryasastrawan@gmail.com \\ I Gede Surya Darmawan, S.T., M.T. \\ Dosen Jurusan Teknik Arsitektur, Fakultas Teknik, Universitas Warmadewa, Denpasar-Bali \\ E-mail: gdsuryadarmawan@gmail.com
}

\begin{abstract}
Abstrak
Manusia akan selalu berusaha mengkondisikan lingkungannya untuk tercapainya kenyamanan termal bagi tubuhnya. Dalam mengkondisikan lingkungan ruang luarnya tersebut sangat dipengaruhi oleh kondisi iklim. Dengan kata lain kenyamanan yang dirasakan manusia di ruang luar sangat tergantung kondisi termal lingkungan tersebut. Obyek ruang luar dalam penelitian ini merupakan lingkungan binaan dengan wujud Taman Kota I Gusti Ngurah Agung di Kota Denpasar. Taman Kota sebagai obyek penelitian selama ini hanya dinilai dari fungsinya sebagai sarana rekreasi yang nyaman bagi masyarakat kota, baik dari kenyamana visual maupun dari kenyamana termal. Untuk menjawab kebutuhan kenyamanan termal dalam taman kota maka fokus penelitian ini adalah pengkondisian elemen ruang luar dengan konsep Arsitektur Tradisional Bali untuk meningkatkan kenyamana termal dari kondisi esksisting. Tujuan penelitian ini untuk menghasilkan optimalisasi kenyamanan termal taman kota melalui rekomendasi model penataan dengan konsep Taman Air Arsitektur Tradisional Bali. Dibutuhkan visualisasi kondisi termal menggunakan software Envi-MET 3.1 untuk melihat peningkatan kenyamanan termal pada model rekomendasi obyek penelitian. Adapun hasil dari penelitian ini adalah pemetaan peningkatan sebaran kuantitas kenyamanan termal pada kondisi model rekomendasi taman kota. Dari pemetaan sebaran kondisi termal tersebut diketahui bahwa tingkat kenyamana termal pada model rekomendasi taman kota lebih tinggi. Hasil ini kemudian dapat ditindaklanjuti sebagai rekomendasi model Taman Kota I Gusti Ngurah Made Agung dengan konsep Taman Air Arsitektur Tradisional Bali serta kedepannya dapat diterapkan di kota - kota lain dengan karakteristik serupa.
\end{abstract}

Kata Kunci: Kenyamanan Termal, Arsitektur Tradisional Bali, Taman Kota.

\begin{abstract}
People will always try to condition his environment to achieve thermal comfort for his body. To conditioning the external environment is strongly influenced by climatic conditions. In other words, the comfort that humans feel in the outer space is depend on the thermal conditions of the environment. The object of outer space in this research is the built environment with the shape of Taman Kota I Gusti Ngurah Agung in Denpasar City. City Park as the object of research so far only judged from its function as a convenient recreational facility for the city community, both from the visual comfort and the thermal comfort. To answer the needs of thermal comfort in the city park, the focus of this research is the conditioning of the outer space elements with the concept of Balinese Traditional Architecture to improve the thermal comfort of the esksisting conditions. The purpose of this research is to produce thermal comfort optimization of city park through recommendation of arrangement model with the concept of Water Garden of Traditional Architecture of Bali. It takes thermal condition visualization using Envi-MET 3.1 software to see thermal enhancement improvement in the research object recommendation model. The result of this research is mapping of the increase of thermal comfort quantity distribution at the condition of urban park recommendation model. From the mapping of the thermal conditions, it is known that the thermal comfort level of the urban park recommendation model is higher. This result can then be followed up as a recommendation model of Taman Kota I Gusti Ngurah Made Agung with the concept of Water Garden of Traditional Architecture of Bali and the future can be applied in other cities with similar characteristics.
\end{abstract}


Keywords: Thermal Comfort, Balinese Traditional Architecture, City Park.

\section{Pendahuluan}

Manusia dengan kemampuan beradaptasi dan kreatifitasnya akan berusaha memodifikasi lingkungan tempat mereka berkativitas hingga kebutuhan akan kenyamanan mereka dapat tercapai (Mahdavi \& Kumar, 1996). Kenyamanan dalam hal ini lebih kepada dampak yang diberikan dari kondisi termal lingkungan terhadap kenyamanan tubuh manusia itu sendiri. Maka untuk mengetahui dampak tersebut perlu kiranya melihat kondisi secara nyata melalui obyek-obyek karya cipta manusia itu sendiri. Sehingga dapat diketahui karya tersebut sudah dapat memberikan kenyamananan termal atau tidak.

Salah satu karya cipta manusia yang menarik untuk dikaji dari hal kenyamanan termal adalah lingkungan binaan berupa taman air. Di daerah tertentu seperti di Bali khususnya, telah ditemukan banyak taman-taman tradisionl yang hampir semua menerapkan elemen air. Menurut Mugi Raharja (2010) hakikat konsep filosofis desain taman air tradisional peninggalan kerajaan-kerajaan di Bali adalah perlindungan terhadap sumber mata air alam (kelebutan). Menariknya lagi menurut penelitian Wirya, dkk (2016) bahwa pada obyek Taman Air Tradisional di Bali dengan konsep Arsitektur Tradisional Bali (ATB) memiliki keunggulan dalam memberikan peningkatan kenyamana termal pada penggunanya.

Melihat peluang diatas, maka perlu dilakukan pengembangan berupa konsep desain taman air berarsitektur Tradisional Bali untuk diterapkan kedalam sebuah wadah baru dalam konteks kekinian berupa obyek taman kota. Taman kota sebagai wadah rekreasi bagi masyarakat kota dipandang relefan untuk dikembangkan ke arah lebih baik yang tidak hanya nyaman dari sisi visual tetapi juga nyaman dari sisi termal. Sehingga nantinya dengan menerapkan konsep taman air ATB akan diperoleh model rekomendasi taman kota dengan tingkat kenyamanan termal yang optimal.

Untuk menguji dan menemukan model rekomendasi taman kota maka dipilih studi khasus Taman Kota I Gusti Ngurah Made Agung di Denpasar. Taman kota ini di pilih karena memiliki karakter yang dapat mewakili beberapa taman kota dan merupakan taman kota pertama yang ada di Kota Denpasar. Sedangkan Kota Denpasar sendiri dipilih karena memiliki kondisi iklim paling ekstrim di wilayah Bali, sehingga bila nantinya pada obyek ini diperoleh kenyamanan termal yang optimal maka dapat dipastikan di tempat lain juga berdampak sama. Nantinya model rekomendasi ini dapat dijadikan acuan bagi perancangan taman kota kedepannya.

\section{Metode Penelitian}

Dalam penelitian ini, untuk mengetahui kualitas kenyamanan termal serta pola penataan yang mempengaruhi kondisi termal di obyek penelitian, maka metoda yang digunakan dalam penelitian ini adalah metode eksperimental melalui simulasi dengan aplikasi komputer yaitu Envi-MET 3.1 dan Comfort Calculator.

Dalam pengumpulan data dilakukan dengan cara observasi lapangan untuk memperoleh data pengukuran lapangan seperti kondisi termal dan kondisi fisik obyek penelitian. Dalam observasi selain dilakukan pengamatan kondisi eksisting, juga dilakukan pengukuran kondisi termal (suhu, kelembaban, kecepatan dan arah angin) sebanyak tiga periode waktu dalam satu hari. Tiga periode pengukuran yang dimaksud yaitu; pagi (07.00 - 
09.00), siang (11.00 - 13.00), dan sore (pk 15.00 - 17.00). Kegiatan ini dilakukan dalam rentan wakut 3 hari berturut - turut.

Analisis dilakukan terhadap hasil simulasi yang diperoleh dari software Envi-MET 3.1 untuk mengetahui sebaran kondisi termal dan komponen yang mempengaruhi kondisi termal di obyek penelitian. Hasil simulasi ini juga digunakan untuk melihat peranan pola penataan dan elemen ruang luar taman air terhadap kenyamanan termal yang dihasilkan di obyek penelitian. Dengan mengetahui peran dari pola dan setiap elemen ruang luar tersebut, maka di mungkinkan untuk merencanakan / merekomendasikan sebuah rancangan taman kota yang memberikan kenyamanan termal untuk di aplikasikan oleh masyarakat.

\section{Analisis dan Pembahasan}

Berdasarkan pengamatan lapangan maka obyek taman kota yang dipilih sebagai sample penelitian adalah Taman Kota I Gusti Made Agung. Taman kota ini dipilih karena dapat mewakili beberapa karakteristik taman kota yang ada di Kota Denpasar seperti; lokasinya berada di pusat kota, memiliki karakteristik aktivitas pengguna yang beragam, dan memiliki karakteristik elemen ruang luar cukup beragam yang dapat mewakili karakteristik taman kota lainnya.

Untuk mempermudah dan mendapatkan data yang akurat, maka dalam proses pengamatan dan pengukuran taman kota dibagai kedalam 6 (enam) zona. Masing-masing zona dapat diuraikan sebagai berikut:

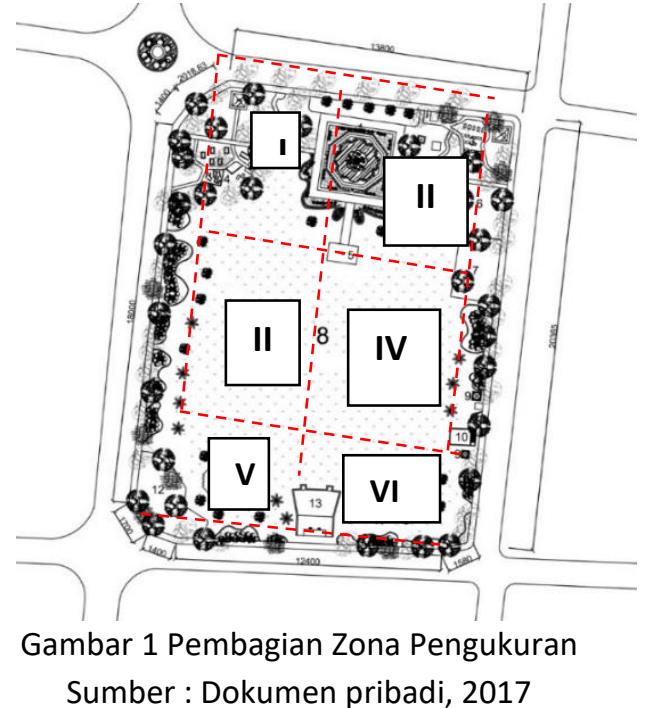

\subsection{Pengidentifikasian Kondisi Eksisting}

Ruang luar merupakan lingkungan alam kita yang dapat dibedakan atas, batu, tumbuhtumbuhan, binatang dan iklim, serta dipengaruhi hal lainnya yaitu suhu, kelembaban udara, cahaya dan bobot beserta perwujudan materi, yaitu padat, cair, dan gas (Heinz Frick, 1996). Sejalan dengan kutipan tersebut maka pada tahap ini bertujuan untuk mengetahui kondisi eksisting elemen ruang luar yang mempengaruhi kondisi termal di lapangan. Di dalam area Lapangan Puputan Badung terdapat beberapa zona yang menarik masyarakat untuk beraktifitas di sana. Zona Utara dari Lapangan ini sangat identik dengan Patung Pejuang Puputan yang dilengkapi dengan kolam air mancur disekitarnya dengan penataan ruang luar yang sangat indah. Fasilitas yang ada di 
Lapangan Puputan Badung antara lain, area bermain anak (play ground area), area bermain catur, panggung terbuka (open stage), lapangan rumput, jogging track, toilet, dan bangku taman.

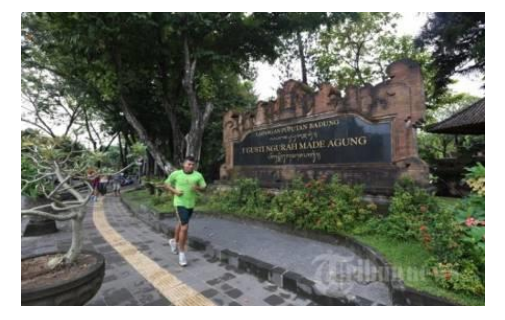

1. Petanda Nama

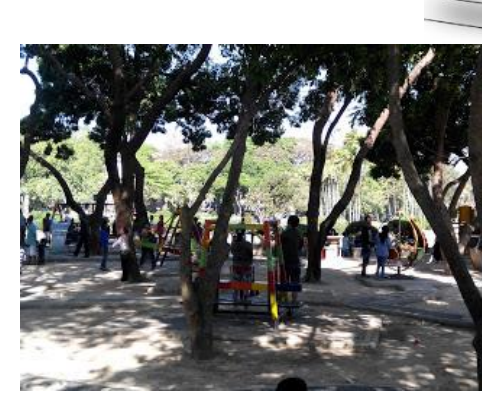

8. Arena bermain

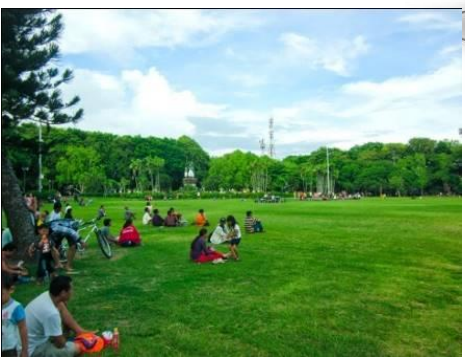

7. Ruang terbuka Sisi barat

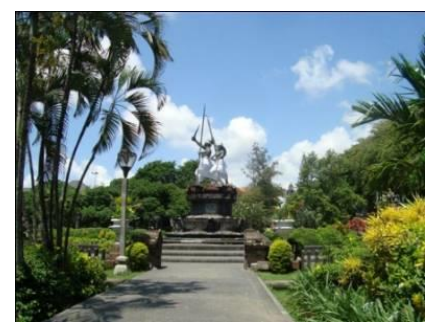

2. Zona Patung

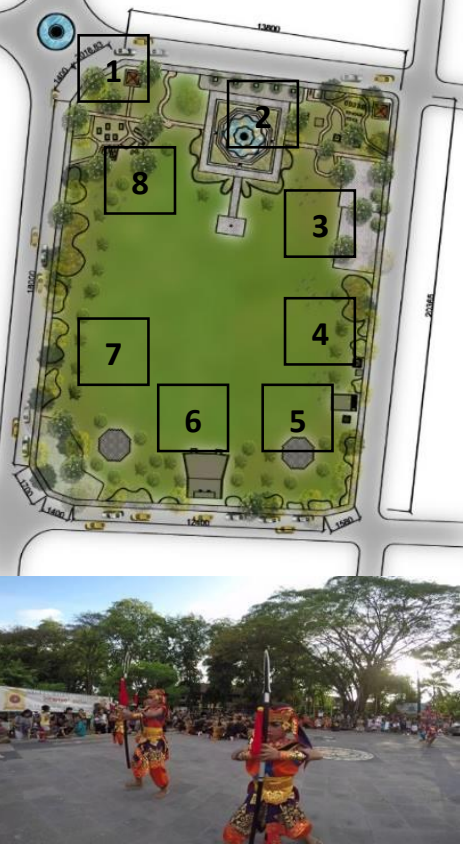

6. Area open stage

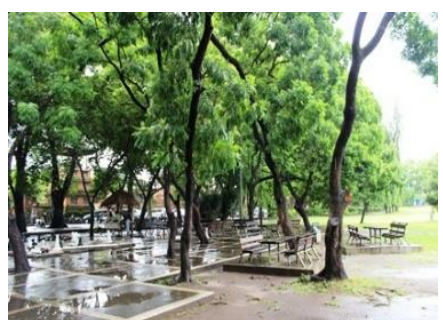

3. Area Duduk dan Main

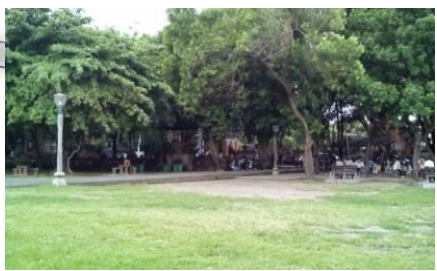

4. Area sisi timur lapangan

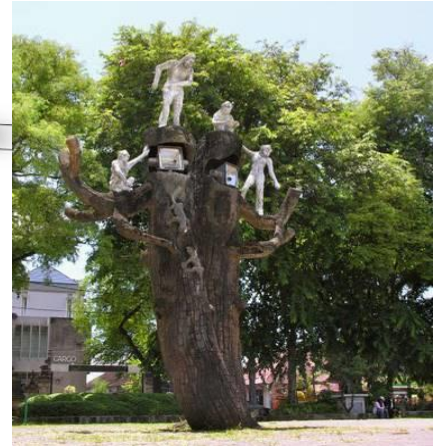

5. Area Patung Monyet

Gambar 2 Fungsi di dalam Lapangan Puputan I Gusti Ngurah Made Agung Sumber: Dokumen pribadi, 2017

\subsection{Analisis Kondisi Termal dan Simulasi Software Envi-Met 3.1}

Pengidentifikasian kondisi termal eksisting ini sangat dipenting untuk dilakukan karena data ini akan sangat mempengaruhi kondisi kenyamanan termal penguna di dalamnya. Menurut Sugini (2007), bahwa kenyamanan termal adalah kondisi pikiran yang mengekspresikan kepuasan dengan lingkungan termalnya. Untuk itu diperlukan pengukuran kondisi termal dimana menurut Fanger (1982) dalam penciptaan kenyamanan termal terdapat enam variable yang harus diperhatikan, yaitu: (1) Temperatur udara, (2) Temperatur radian rata-rata, (3) Kecepatan udara relative, (4) Kelembaban udara relative, (5) Tingkat aktifitas, (6) Thermal resistance dari pakaian. 
A. Hasil Pengukuran Kenyamanan Termal

Hasil pengukuran termal dilakukan 3 kali pada waktu pengukuran yang berbeda dalam satu hari. Adapun alat ukur yang digunakan mampu memunculkan kondisi Suhu, Kelembaban dan kecepatan angin.

Tabel 1 Rata-rata Hasil Pengukuran Temperatur Udara

\begin{tabular}{|c|c|c|c|c|c|c|}
\hline WAKTU & ZONA I & ZONA II & ZONA III & ZONA IV & ZONA V & ZONA VI \\
\hline $07.00-09.00$ & 26.1 & 25.1 & 28.7 & 27.6 & 27.4 & 26.3 \\
\hline $11.00-13.00$ & 29.8 & 28.9 & 31.6 & 30.6 & 30.6 & 29.8 \\
\hline $15.00-17.00$ & 28.6 & 27.3 & 30.8 & 29.7 & 29.7 & 28.6 \\
\hline
\end{tabular}

*dalam satuan : ${ }^{\circ} \mathrm{C}$

Tabel 2 Rata-rata Hasil Pengukuran Kelembaban Udara $(\mathrm{RH})$

\begin{tabular}{|c|c|c|c|c|c|c|}
\hline WAKTU & ZONA I & ZONA II & ZONA III & ZONA IV & ZONA V & ZONA VI \\
\hline $07.00-09.00$ & 68.5 & 67.4 & 65.7 & 71.9 & 71.1 & 70.3 \\
\hline $11.00-13.00$ & 64.9 & 64.7 & 56.4 & 68.5 & 67.2 & 67.1 \\
\hline $15.00-17.00$ & 67.7 & 67.4 & 66.4 & 69.1 & 68.4 & 68.2 \\
\hline
\end{tabular}

*dalam satuan : persentase

Tabel 3 Rata-rata Hasil Pengukuran Kecepatan Angin

\begin{tabular}{|c|c|c|c|c|c|c|}
\hline WAKTU & ZONA I & ZONA II & ZONA III & ZONA IV & ZONA V & ZONA VI \\
\hline $07.00-09.00$ & 2.3 & 2.9 & 0.8 & 1.1 & 1.4 & 1.9 \\
\hline $11.00-13.00$ & 3.6 & 3.9 & 2.9 & 3.1 & 3.2 & 3.4 \\
\hline $15.00-17.00$ & 2.1 & 2.1 & 1.8 & 1.9 & 2.0 & 2.1 \\
\hline
\end{tabular}

*dalam satuan: $\mathrm{m} / \mathrm{s}$

Pengukuran suhu, kelembaban dan kecepatan angin merupakan rata-rata hasil pengukuran selama 3 hari dengan 3 periode waktu berbeda. Untuk data suhu bila dibandingkan dengan skala s suhu pada sensasi kenyamanan termal (Sugini, 2007), maka diperoleh tingkat suhu yang terukur diatas termasuk pada skala yang ditunjukan pada tabel 4. 
Tabel 4 Kenyamanan termal sesuai standar level suhu terukur

\begin{tabular}{|c|c|c|c|c|c|c|}
\hline WAKTU & ZONA I & ZONA II & ZONA III & ZONA IV & ZONA V & ZONA VI \\
\hline $\begin{array}{c}07.00- \\
09.00\end{array}$ & nyaman & $\begin{array}{c}\text { Agak } \\
\text { sejuk }\end{array}$ & $\begin{array}{c}\text { Agak } \\
\text { hangat }\end{array}$ & $\begin{array}{c}\text { Agak } \\
\text { hangat }\end{array}$ & $\begin{array}{c}\text { Agak } \\
\text { hangat }\end{array}$ & Nyaman \\
\hline $\begin{array}{c}11.00- \\
13.00\end{array}$ & $\begin{array}{c}\text { Agak } \\
\text { hangat }\end{array}$ & $\begin{array}{c}\text { Agak } \\
\text { hangat }\end{array}$ & $\begin{array}{c}\text { Agak } \\
\text { hangat }\end{array}$ & $\begin{array}{c}\text { Agak } \\
\text { hangat }\end{array}$ & $\begin{array}{c}\text { Agak } \\
\text { hangat }\end{array}$ & $\begin{array}{c}\text { Agak } \\
\text { hangat }\end{array}$ \\
\hline $\begin{array}{c}15.00- \\
17.00\end{array}$ & $\begin{array}{c}\text { Agak } \\
\text { hangat }\end{array}$ & $\begin{array}{c}\text { Agak } \\
\text { hangat }\end{array}$ & $\begin{array}{c}\text { Agak } \\
\text { hangat }\end{array}$ & $\begin{array}{c}\text { Agak } \\
\text { hangat }\end{array}$ & $\begin{array}{c}\text { Agak } \\
\text { hangat }\end{array}$ & $\begin{array}{c}\text { Agak } \\
\text { hangat }\end{array}$ \\
\hline
\end{tabular}

Mengacu pada teori bukan hanya suhu yang menjadi faktor dalam menentukan kenyamanan termal, maka ini merupakan hasil pendekatan sementara. Pada table menunjukan rata-rata tingkat kenyamanan termal di obyek menunjukan kondisi agak hangat. Hasil indentifikasi diatas juga dapat di perkuat dengan Indeks PMV (Predicted Mean Vote) yang diusulkan oleh P.O. Fanger tahun 1970 kemudian diratifikasi dan mendapat ISO 7748. Dalam indeks PMV sensasi termal diskalakan dengan menggunakan tujuh titik skala psikofisis dari ASHRAE yaitu: $-3,-2,-1,0,1,2,3$ yang memiliki kondisi "dingin, sejuk, agak sejuk, netral atau nyaman, agak hangat, hangat, dan panas".

\section{B. Simulasi Kondisi Eksisting dan Model Rekomendasi Taman Kota}

Berdasarkan penelitian Wirya, dkk (2016), tata letak kolam air pada Taman Air ATB maka dapat dikelompokan dalam tiga Model yaitu:

a. Model I, model taman dengan beberapa (3-5) kolam air yang menutupi hampir $80 \%$ permukaan site dan kolam tersebar di dalam areal site. Obyek penelitian yang termasuk dalam obyek ini yaitu Taman Soekasada dan Taman Tirta Gangga.

b. Model II, model taman dengan 2 kolam air yang masing-masing mengelilingi keseluruhan site dan kolam di dalam site yang mengelilingi sebagian areal site. Obyek penelitian yang termasuk dalam model ini yaitu Pura Taman Ayun.

c. Model III, model taman yang terdiri dari 2-3 kolam utama dan berada di tengah site. Obyek penelitian yang termasuk dalam model ini yaitu Pura Tirta Empul dan Pura Goa Gajah.
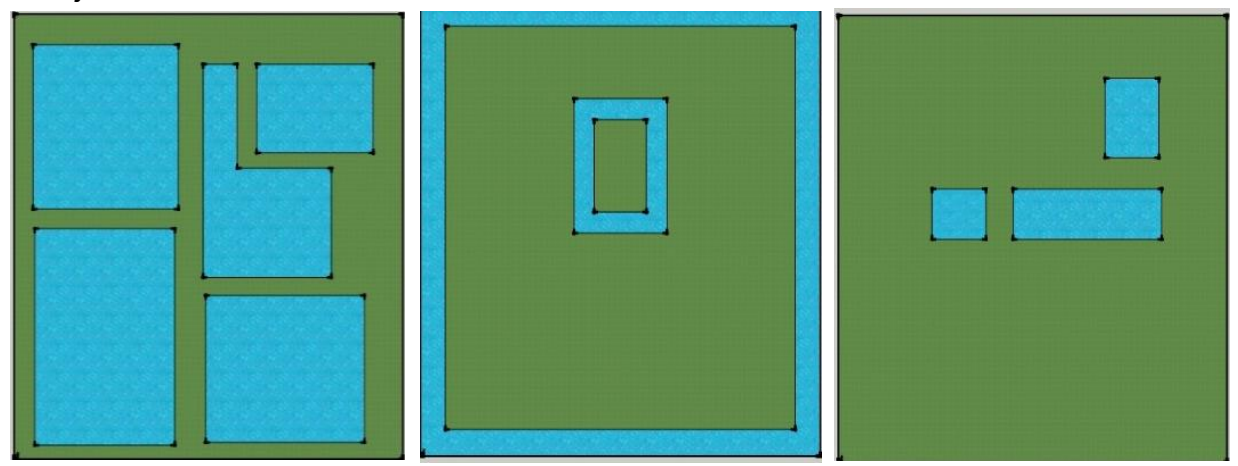

Gambar 3. Model Taman Air Arsitektur Tradisional Bali

(dari kiri Model I, Model II, dan Model III)

Sumber : Wirya, dkk (2017)

Melihat ke tiga model di atas dapat dikatakan elemen air tidak terlepaskan dari konsep penataan Taman Air ATB. Bila dikaitkan dengan teori, keberadaan elemen air sebagai 
bagian dari elemen ruang luar dapat berguna sebagai unsur pendingin pada waktu cuaca panas karena air dapat memperbesar kelembaban dan semakin besar kawasan air maka semakin besar dampak yang mungkin terjadi pada iklim mikronya (Laurie, 1986). Adapun model rekomendasi yang akan diajukan adalah dengan menggunakan pendekatan Model II, karena kondisi ini yang paling relefan dapat diterapkan pada site taman kota I Gusti Ngurah Made Agung. Pendekatan model II tersebut juga dilengkapi dengan penerapan konsep Sanga Mandala sebagai zoning ruang sebagai pendekatan fungsi dan fasilitas di dalam taman kota nantinya.

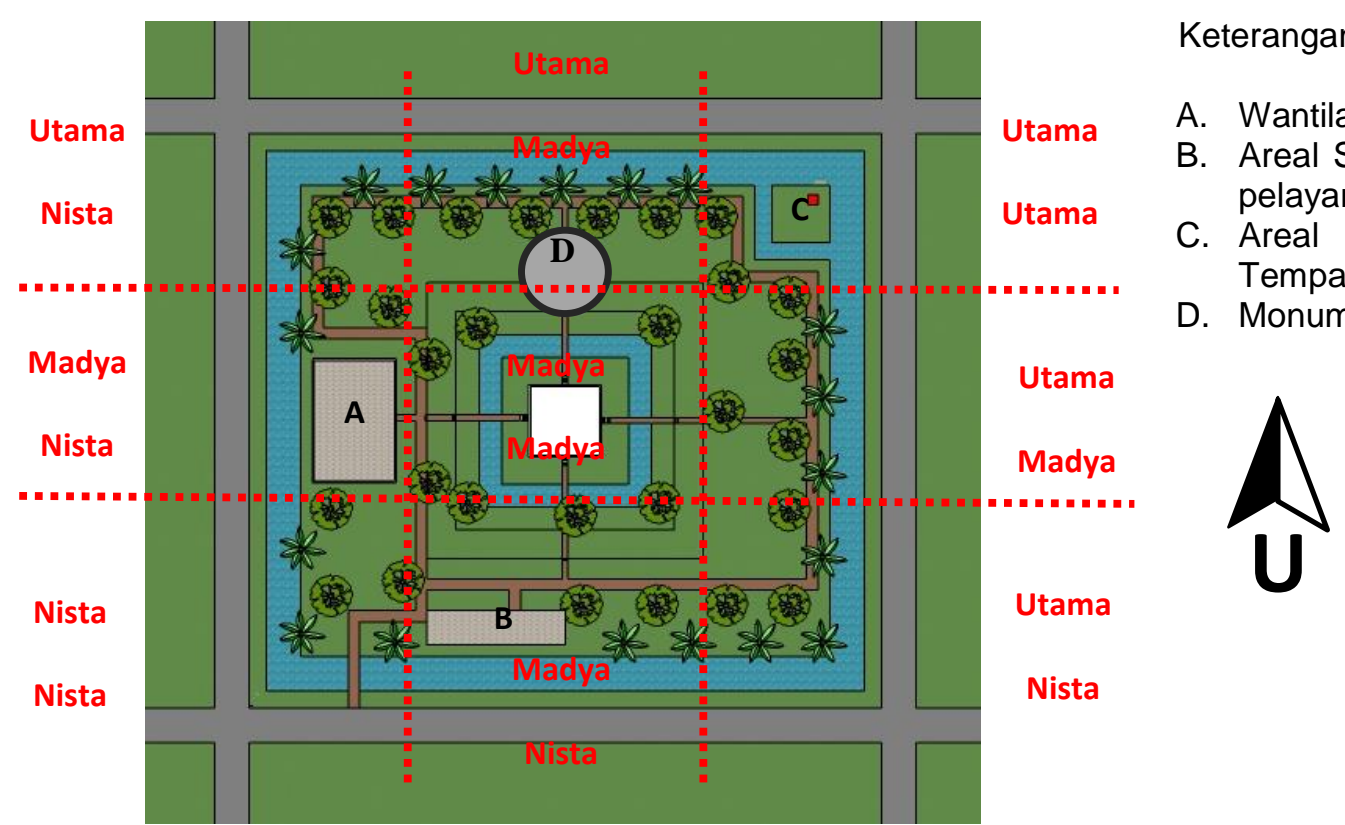

Gambar 5. Rekomendasi Model Taman Air Arsitektur Tradisional Bali

Pada tahap selanjutnya, dari pendataan kondisi eksisting dilapangan dan hasil pengukuran dimanfaatkan sebagai informasi dasar untuk diinput kedalam simulasi EnviMET 3.1. Input data juga dimodivikasi dengan model rekomendasi taman air untuk diterapkan pada Taman Kota I Gusti Made Agung. Hasil simulasi ini (tabel 5) dapat menunjukan sebaran tingka kondisi termal pada obyek penelitian sehingga diketahui tingakat kenyamanan termal pada model rekomendasi. 
Tabel 5. Hasil Simulasi Model Rekomendasi Taman Kota I Gusti Ngurah Made Agung

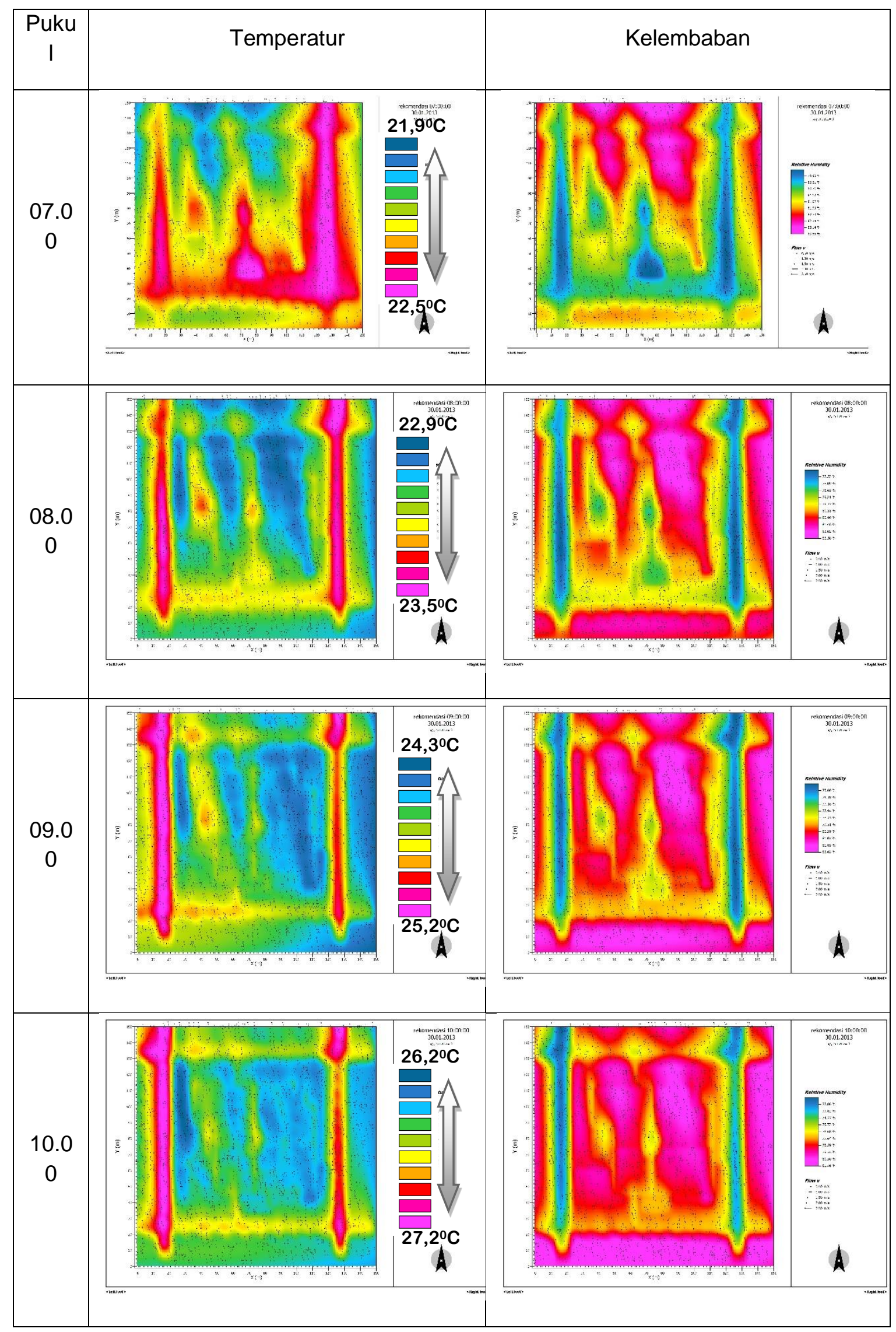




\begin{tabular}{|c|c|c|c|c|}
\hline $\begin{array}{c}11.0 \\
0\end{array}$ & 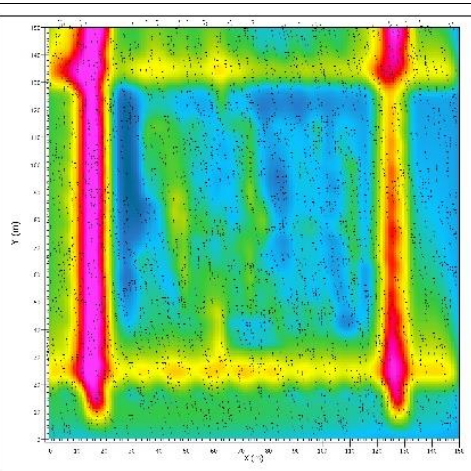 & $27,2^{\circ} \mathrm{C}$ & $\left(||^{(S)}\right.$ & 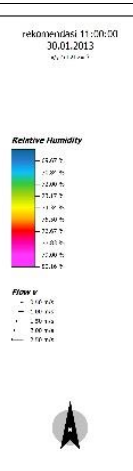 \\
\hline $\begin{array}{c}12.0 \\
0\end{array}$ & $\left(\begin{array}{l}x^{2} \\
\end{array} \mid\right.$ & $27,8^{\circ} \mathrm{C}$ & 4 & 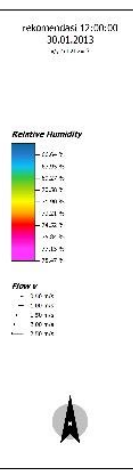 \\
\hline $\begin{array}{c}13.0 \\
0\end{array}$ & (1) & 28, 10 C & 4 & 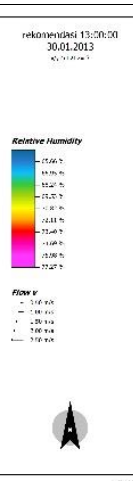 \\
\hline $\begin{array}{c}14.0 \\
0\end{array}$ & $(\mid) \mid(\mid)$ & 28, & $\left(\int^{(S)}\right.$ & 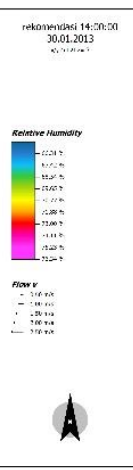 \\
\hline
\end{tabular}




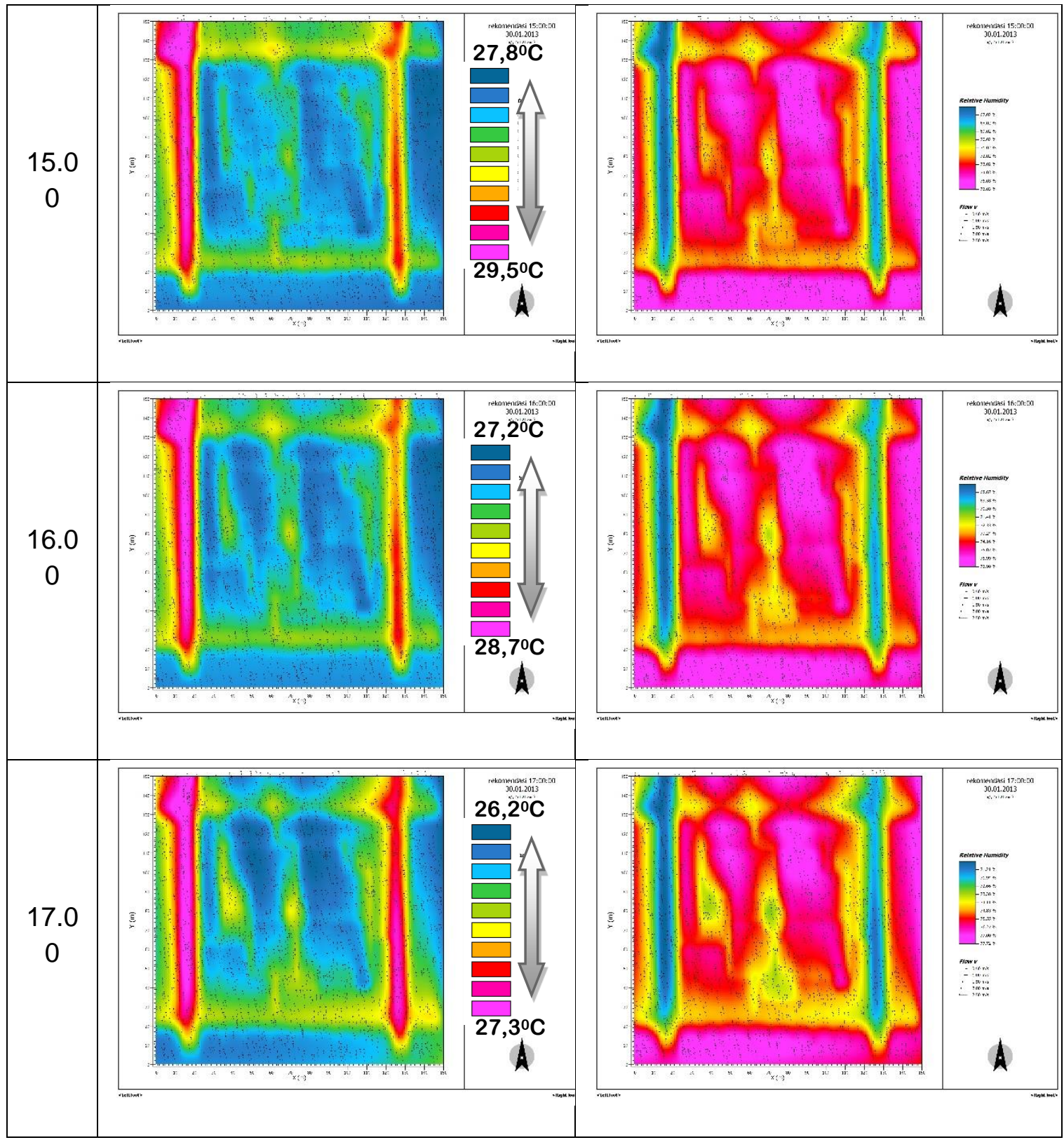

Berdasarkan hasil simulasi Envi-MET 3.1. di atas menunjukan sebaran kondisi termal terutama temperature udara pada titik tertinggi yaitu pada pukul 13.00 hanya mencapai 29,8 C. Sedangkan temperature tertingi pada hasil pengukuran kondisi termal eksisting di lapangan mencapai 31,6 C. ini menunjukan model rekomendasi dengan pendekatan konsep desain Arsitektur Tradisional Bali dapat memberikan peningkatan kenyamanan termal. Berdarkan simulasi ini pula diperoleh hasil rata-rata temperature pada pukul 07.00 - 10.00 yaitu 25,6 C (Nyaman/Netral), pukul 11.00 - 13.00 yaitu 28,5 C (Agak Hangat), dan pukul 14.00 - 17.00 yaitu 26,8 (Nyaman/Netral. Data tersebut menunjukan kenyamanan termal pada model rekomendasai depanjang hari di dominasi oleh kondisi Nyaman/Netral. Dalam simulasi juga menunjukan sebaran tingkat temperatur rendah berada disekitar areal kolam. Ini mengindikasikan bahwa penyejukan evaporasi oleh air berdampak signifikan pada penurunan temperature udara. Hasil tersebut sejalan dengan Snyder dan Catanase (1989) yang menyatakan bahwa permukaan air dapat menyerap panas, menyimpannya, dan memancarkannya kembali ke atmosfir dalam satu periode 
dan proses ini berlangsung untuk menyamakan perbedaan suhu harian di tapak-tapak yang bersebelahan.

\section{Penutup}

Berdasarkan pembahasan serta analisis yang dipaparkan sebelumnya maka diperoleh kesimpulan sebagai berikut:

1. Tingkat kenyamanan termal berdasarkan hasil pengukuran dan pengamatan di Taman Kota I Gusti Ngurah Made Agung menunjukan kondisi “agak hangat” tersebut masih dalam range nyaman.

2. Tingkat kenyamanan termal sepanjang hari berdasarkan hasil simulasi model rekomendasi Taman Kota I Gusti Ngurah Made Agung didominasi dengan kondisi Nyaman/Netral.

3. Model II dari penelitian Wirya, dkk (2016) dapat dijadikan sebagai acuan dasar pendekatan model dala perancangan taman kota.

4. Hasil simulasi menunjukan keberadaan elemen air yang mengelilingi taman kota memberikan dampak peningkatan kenyamanan termal.

\section{Ucapan Terima Kasih}

Terima kasih diucapkan kepada Kementrian Riset, Teknologi, dan Pendidikan Tinggi Republik Indonesia (KEMENRISTEKDIKTI) karena telah mendanai penelitian ini secara penuh dalam rangka hibah penelitian dosen pemula tahun pelaksanaan 2017. Ucapan terima kasih juga diucapkan kepada lembaga penelitian Universitas Warmadewa yang telah menjembatani kerjasama antara tim peneliti dengan KEMENRISTEKDIKTI sehingga dapat berjalan dengan semestinya.

\section{Daftar Pustaka}

Fanger, P.O. 1982. Thermal Comfort: Analysis and Applications in Environmental Engineering. New York : Danish Technical Press.

Heinz Frick. 1996. Arsitektur dan Lingkungan. Yogyakarta : Kanisius.

Laurie, M. 1986. Pengantar Kepada Arsitektur Pertamanan. Bandung : Intermatra.

Mahdavi, A. and Kumar, S. 1996. Implications of Indoor Climate Control for Comfort, Energy, and Environment. Energy and Buildings.

Snyder, J.C., catanese, A.J. 1989. Pengantar Arsitektur. Jakarta : Erlangga.

Sugini. 2007. Model Kenyamanan Termal Termo Adaptif Psikologis Pada Ruang Dalam Bangunan Di Yogyakarta. Yogyakarta : Universitas Gadjah Mada.

Wirya, dkk. 2016. Simulasi Kenyamanan Termal Pada Taman Air Tradisional Di Bali. Jurnal Undagi Vol.4/No.1. Denpasar : Universitas Warmadewa. 